$3 z>$

UCRL 7488

$12 / 14 / 63$

\author{
University of California \\ Ernest 0 . Lawrence \\ Radiation Laboratory
}

Livermore, California 


\section{DISCLAIMER}

This report was prepared as an account of work sponsored by an agency of the United States Government. Neither the United States Government nor any agency Thereof, nor any of their employees, makes any warranty, express or implied, or assumes any legal liability or responsibility for the accuracy, completeness, or usefulness of any information, apparatus, product, or process disclosed, or represents that its use would not infringe privately owned rights. Reference herein to any specific commercial product, process, or service by trade name, trademark, manufacturer, or otherwise does not necessarily constitute or imply its endorsement, recommendation, or favoring by the United States Government or any agency thereof. The views and opinions of authors expressed herein do not necessarily state or reflect those of the United States Government or any agency thereof. 


\section{DISCLAIMER}

Portions of this document may be illegible in electronic image products. Images are produced from the best available original document. 
UCR L- 7488

Chemistry, UC-4

TID-4500 (22nd Ed.)

\begin{abstract}
UNIVERSITY OF CALIFORNIA
Lawrence Radiation Laboratory
\end{abstract}

Livermore. California

Contract No. W-7405-eng-48

A ROD-CONDUCTION RADIOMETRIC CALORIMETER

Stuart R. Gunn

$!$

September 11, 1963 


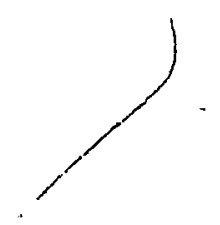

Printed in USA. Price 50 cents. Available from the office of Technical Services U. S. Department of Commerce Washington 25 , D. C. 
A ROD-CONDUCTION RADIOMETRIC CALORIMETER

\author{
Stuart R. Gunn \\ Lawrence Radiation Laboratory, University of California \\ Livermore, California \\ September 11,1963
}

\begin{abstract}
A twin rod-conduction calorimeter for routine assay of small radioactive sources is described. The equilibration time is about forty minutes and the detection limit about $1 \times 10^{-4}$ watt. A thermistor circuit and nonlinear potentiometer are used for the differential temperature measurement. Use of a plutonium sample for calibration is described.
\end{abstract}




\title{
A ROD-CONDUCTION RADIOMETRIC CALORIMETER
}

\author{
Stuart R. Gunn \\ Lawrence Radiation Laboratory, University of California \\ Livermore, California \\ September 11, 1963
}

Several calorimeters used for the assay of radioactive materials at this Laboratory have been described previously. Most of these are isothermal steady-state heat-flow types having cylindrical conduction gaps, filled with air or solid conducting media, surrounding the sample chamber; the temperature gradient is measured with resistance thermometers ${ }^{1,2}$ or thermocouples. ${ }^{3}$ Water-flow types have also been used. ${ }^{2}$ The general field of radiometric calorimetry is reviewed elsewhere. ${ }^{4}$

The present instrument was required for routine as say of samples producing easily absorbed radiations at power levels up to a few tenths of a watt with a detection limit of a few tenths of a milliwatt and an accuracy for larger samples of $0.5 \%$ or better. The instrument was to be robust and simple in operation to permit use by inexperienced personnel with a minimum requirement of operator time. Measurements were to be completed in approximately one-half hour. It was decided to avoid the problem of electrical calibration by using a long-lived radioactive source, standardized in another calorimeter, to calibrate this instrument. This was practical because the sample containers for unknowns were to be all the. same and the calibrating source could be put in one of them. In this manner, the calorimeter becomes truly a comparison instrument, and many problems of design and operation are simplified. In particular, minimization of the heat distribution error - the differences in signals produced by samples of the same power but of different geometries and at different positions in the sample chamber - is no longer of importance.

A rod-conduction type was adopted for robustness and ease of construction, with a simple and sensitive thermistor bridge for temperature measurements. Twin construction minimizes the effect of bath fluctuations. A cross section of the calorimeter, laboratory designation XX, is shown in Fig. 1. The conduction rod assemblies are made of hard copper tubes, 


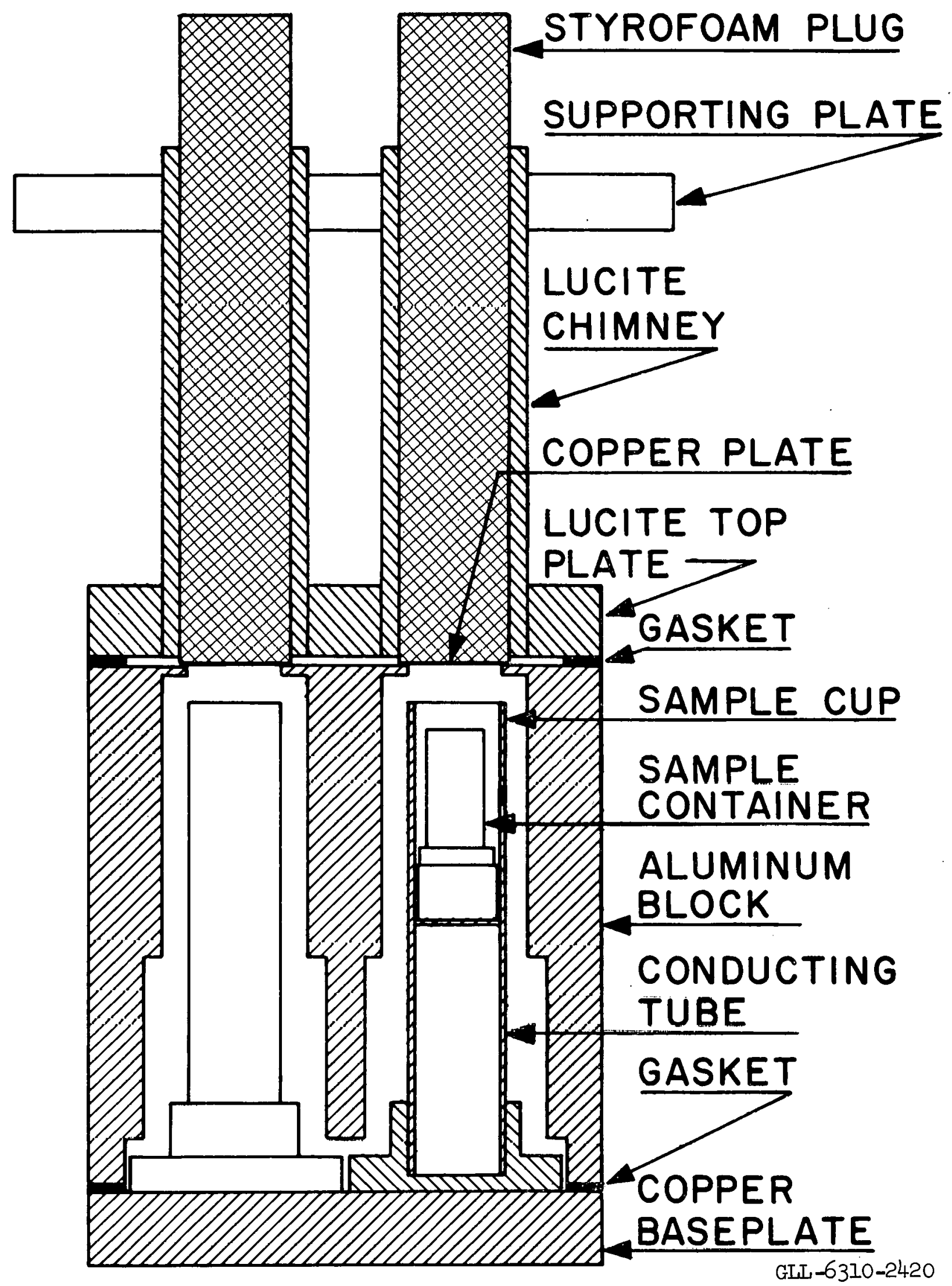

Fig. 1. Calorimeter XX. 
1.25-in. o.d., 0.065-in. wall, 6.50 in. long, soldered into copper bases 1.25 in. high with a central bore $1.25-$ in. in diameter and 1.00 in. deep; the bases are 1.75-in. o.d. with a flange 2.875.in. in o.d. and 0.50 in. thick. A copper plate $0.065 \mathrm{in}$. thick is soldered in the tube $3.00 \mathrm{in}$. below the top, forming a sample cup. The two conduction rod assemblies are screwed to a chrome-plated copper basepläte, $7.00 \mathrm{in}$. in diameter and 1.00 in. thick, a little vacuum grease between the surfaces improving the thermal contact. The rod assemblies are surrounded by an anodized aluminum block, 7.00in. in diameter and 7.125 in. high. This is bored out at the bottom to a 6.00-in. diameter and a 0.625-in. depth; above this two parallel bores on centerlines $3.00 \mathrm{in}$. apart have diameters of $2.50 \mathrm{in}$. for a 2.50-in. length, $2.00 \mathrm{in}$. for a 3.875-in. length, and $1.25 \mathrm{in}$. for a 0.125 -in. length. Above the two conduction tubes are Lucite chimneys, 1.50-in. i.d., closed by Sty rofoam plugs with thin copper plates at the bottom which rest on the aluminum block to complete the isothermal boundary. Electrical leads are attached to a terminal strip on the baseplate behind the tube bases and pass upward through another 0.75 -in. hole in the block and corresponding Lucite chimney.

The calorimeter is immersed in a small water-filled thermostat; controlled by a Hallikainen thermoregulator. Most of the measurements have been made with the bath at about $28.06^{\circ} \mathrm{C}$; thermal leakage from the bath to the room compensates for the heat of stirring and eliminates need of a cooling coil.

Although heaters are not used in the normal mode of operation, one was wound on each sample cup. They are bifilar coils of No. 35 Manganin, with a resistance of about $600 \Omega$, covering the outer surface of the cups from 0.50 to $2.50 \mathrm{in}$. below the top.

Two bead-type thermistors sealed in glass probes are cemented to the conduction tubes $180^{\circ}$ apart, with the beads slightly below the bottom of the sample cup. The resistance of each was approximately $2000 \Omega$ at $25^{\circ} \mathrm{C}$. The bridge circuit and measuring potentiometer are shown in Fig. 2. Here, $a$ and $b$ are the thermistors on one side and $c$ and $d$ those on the other. $D_{1}$ and $D_{2}$ are decade resistance boxes; $R_{1}, R_{2}, R_{3}$, and $R_{4}$ are $1 \%$ precision wire-wound resistors immersed in oil, with resistance values of 40,4000 , 2000 , and $500,000 \Omega$, respectively; and $G$ is a galvanometer. To make a 


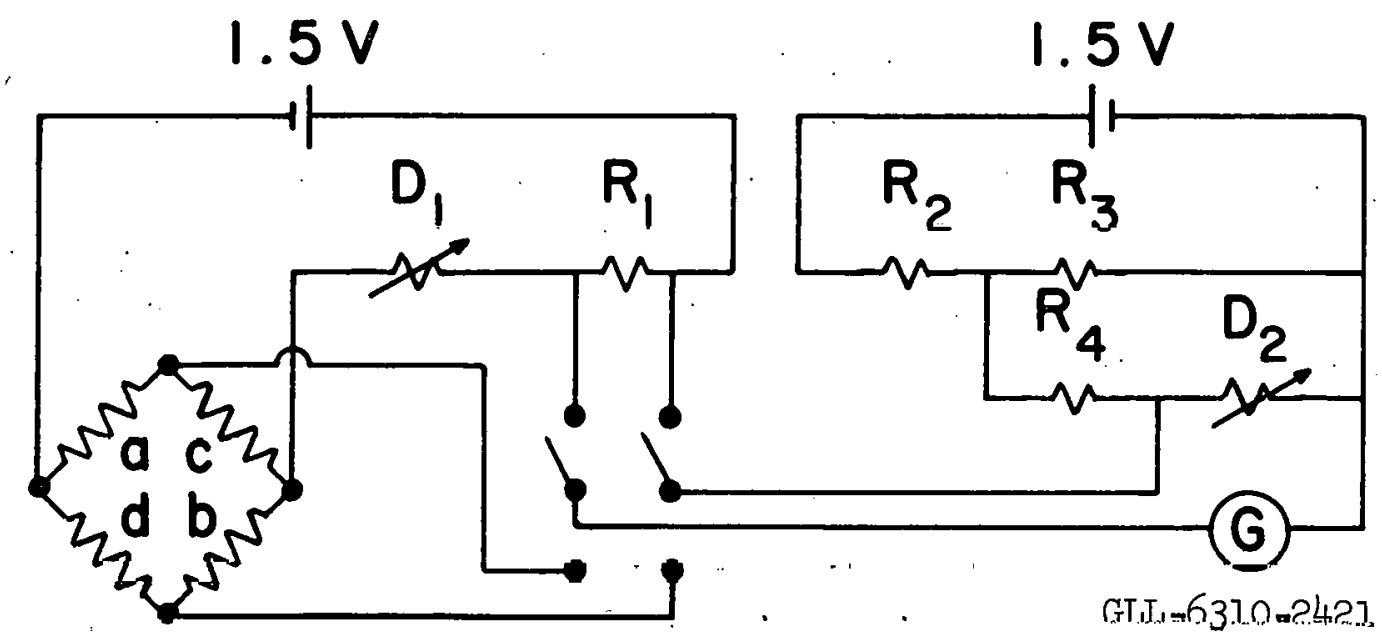

Fig. 2. Bridge and potentiometer circuits. 
reading, the bridge current is first adjusted by setting $D_{2}$ at 9999 , putting the switch in the upper position and adjusting $D_{1}$ to null the galvanometer (the bridge current is then about $0.25 \mathrm{~mA}$ ); the switch is then put in the lower position, $\mathrm{D}_{2}$ is adjusted to null the galvanometer, and the reading of $\mathrm{D}_{2}$ is recorded. The potentiometer circuit characteristics are selected so that the cell is drained at about the same rate as the one supplying the bridge circuit and so that $1 \Omega$ on $D_{2}$ corresponds to about $1 \mu V$. The potentiometer circuit measures the ratio of the output of the bridge to the bridge current; since at a given resistive unbalance of the bridge this ratio is independent of the exact value of the bridge current (except for small differences in the self-heating of the thermistors), no absolute standardization of either input or output potential is necessary.

At the steady-state condition of an isothermal heat flow calorimeter, the sample power and temperature elevation are related by the equation

$$
P=k \Delta T
$$

where $k$ is the heat transfer coefficient. In this instrument heat is transferred partly by air conduction from the sample cup and conducting tube to the block, but mostly by metallic conduction through the copper tube. Since the conductivity of copper changes only about $0.01 \% / \mathrm{deg}, \mathrm{k}$ is constant over the temperature range of interest. However, the bridge output in microvolts is proportional to the resistance change of the thermistors, which is not a linear function of temperature. The resistance-temperature relation of a thermistor is described approximately by

$$
\begin{aligned}
& R=R_{\infty} \exp \left(B T^{-1}\right) \\
& \ln R=\ln R_{\infty}+B T^{-1}, \\
& \log R=\log R_{\infty}+B^{\prime} T^{-1}, \\
& a=d R / R d T=-B T^{-2} .
\end{aligned}
$$

Table I describes the performance of the present thermistor bridge, assuming a resistance of $1800 \Omega$ at $28^{\circ}$ and 1550 for $B^{\prime}$, corresponding to about $-4 \% / \mathrm{deg}$ for $a$. The second column gives the thermistor resistance and the third gives the bridge output in microvolts, which is directly proportional to the resistance change since the bridge is supplied with a constant current. The fourth column gives $\Delta E / \Delta T$, which decreases $2 \% / \mathrm{deg}(4 \% / \mathrm{deg}$ referred to the mean temperature, which corresponds to a). However, the potentiometer 
Table I

\begin{tabular}{ccccccccc}
\hline $\mathrm{T}$ & $\mathrm{R}$ & $\Delta \mathrm{E}$ & $\begin{array}{c}\Delta \mathrm{E} / \Delta \mathrm{T} \\
(\mu \mathrm{V} / \mathrm{deg})\end{array}$ & $\begin{array}{c}\mathrm{D}_{2} \\
(\Omega)\end{array}$ & $\begin{array}{c}\Delta \mathrm{D}_{2} / \Delta \mathrm{T} \\
(\Omega / \mathrm{deg})\end{array}$ & $\mathrm{D}_{2}^{\prime}$ & \multicolumn{1}{c}{$\Delta \mathrm{D}_{2}^{\prime} / \Delta \mathrm{T}$} \\
\hline 28.00 & 1800.0000 & 0 & -- & 0 & -- & 0 & - \\
28.05 & 1796.4621 & 442.24 & 8844.8 & 443.81 & 8876.2 & 444.08 & 8881.60 \\
28.10 & 1792.9326 & 883.42 & 8834.2 & 887.34 & 8873.4 & 888.12 & 8881.21 \\
28.20 & 1785.8977 & 1762.79 & 8814.0 & 1773.72 & 8868.6 & 1776.29 & 8881.46 \\
28.50 & 1764.9857 & 4376.79 & 8753.6 & 4427.25 & 8854.5 & 4441.02 & 8882.04 \\
29.00 & 1730.7650 & 8654.37 & 8654.4 & 8830.31 & 8830.3 & 8882.43 & 8882.43 \\
30.00 & 1664.6240 & 16922.00 & 8461.0 & 17561.33 & 8780.7 & 17763.53 & 8881.76 \\
\hline
\end{tabular}

circuit is nonlinear and partially compensates the nonlinearity of the thermistor; columin 5 gives the calculated values of $\mathrm{D}_{2}$ to balance the circuit and the fifth column gives $\Delta D_{2} / \Delta T$; this decreases only one-fourth as rapidly as $\triangle E / \triangle T$. More judicious selection of circuit parameters can decrease this variation much more; the seventh and eighth columns give calculations for $R_{2}=4480, R_{3}=1520$, and $R_{4}=380,000$.

The thermistors are not exactly balanced; the zero value of $D_{2}$ with no power in either side of the calorimeter is about $1784 \Omega$, which means that the thermistors on the left-hand side (which is used for sample measurements) average about 14.35 less than those on the right side. This bridge zero would be expected from the thermistor characteristics to change about $4 \% / \mathrm{deg}$, and measurements with the bath at 22 and $25^{\circ}$ showed this to be the case. The bridge zero has been found to be stable within about $2 \Omega$ on $D_{2}$ over long periods of time.

In Fig. 1, aisample container is shown in place in the right sample cup. To improve thermal contact, about $15 \mathrm{ml}$ of transformer oil is added to the cup. An empty sample container and the same amount of oil are used in the dummy side to balance the thermal characteristics. When the bridge zero is being measured, each side contains an empty sample container.

Preliminary measurements made with the electrical heaters showed that the sensitivity thus determined is about $1 \%$ less than that determined with the standardized plutonium source. This is in the direction to be expected, since on the average the electrical heater dissipates heat higher on the sample cup and also superheats to a slightly higher temperature than the copper cup. 
Both of these factors tend to increase the temperature at the cup and hence the fraction of heat conducted through the air to the block instead of through the copper tube to the base. Measurements with the plutonium source showed the right side to be about $2 \%$ less sensitive than the left.

The calorimeter is normally calibrated with a plutonium rod of $0.1-\mathrm{W}$ power, enclosed in a standard sample container; this in turn was accurately standardized in calorimeters IV and $V_{0}{ }^{l}$. The sensitivity is about $8400 \Omega / W$, stable and reproducible to about $0.3 \%$ over long periods of time. The halftime ${ }^{l}$ with the standard sample container is about $4 \mathrm{~min}$, permitting completion of measurements in about $40 \mathrm{~min}$. The sample containers are normally stored in a well in the bath for some time before being placed in the calorimeter, so that they: will be near the operating temperature when inserted; this decreases the operating time and minimizes thermal shock to the thermistors.

Plutonium has desirable characteristics as a thermal power standard. $\mathrm{Pu}^{239}$ has a half-life of $24,300 \mathrm{yr}$ and hence decays only $0.00285 \% / \mathrm{yr}$, or $0.1 \%$ in $35.1 \mathrm{yr} . \mathrm{Pu}^{240}$ has a half-life of $6,600 \mathrm{yr}$; a sample containing $90 \%$ $\mathrm{Pu}^{239}$ and $10 \% \mathrm{Pu}^{240}$ would decay $0.1 \%$ in $27.7 \mathrm{yr}$. Both are alpha emitters; 0.15 and $0.21 \%$, respectively, of their powers are in the form of low-energy, easily-absorbed gamma rays. The daughters are long-lived $\mathrm{U}^{235}$ and $\mathrm{U}^{236}$ which give negligible power. The specific power of $\mathrm{Pu}^{239}$ is $0.001907 \mathrm{~W} / \mathrm{g}$ and of $\mathrm{Pu}^{240}$ is $0.00702 \mathrm{~W} / \mathrm{g}$.

However, a difficulty is associated with $\mathrm{Pu}^{24 \mathrm{l}}$. This is a $13-\mathrm{yr}$ beta emitter with a disintegration energy of $0.021 \mathrm{MeV}$ and a specific power of $0.0142 \mathrm{~W} / \mathrm{g}$; its daughter is $458-\mathrm{yr} \mathrm{Am} \mathrm{Am}^{24 \mathrm{l}}$, an alpha emitter with a decay energy of $5.63 \mathrm{MeV}$ and a specific power of $0.1082 \mathrm{~W} / \widehat{\mathrm{g}}$. Figure 3 gives a calculation of the powers of $\mathrm{Pu}^{241}$ and $\mathrm{Am}^{241}$ in a mixture initially 99.900 at. $\mathrm{Pu}^{239}$ and 0.100 at. $\mathrm{Pu}^{241}$, the powers being long-lived plutonium. If the mixture contained $\mathrm{Pu}^{240}$, these percentages would be reduced since the power of the $\mathrm{Pu}^{239}$ and $\mathrm{Pu}^{240}$ would be greater than that of $\mathrm{Pu}^{240}$ alone; for ' example, if the mixture consisted of $94.900 \% \mathrm{Pu}^{239}, 5.000 \% \mathrm{Pu}^{240}$, and $0.100 \% \mathrm{Pu}^{241}$, the percentages in Fig. 3 would be reduced by a factor of 1.134. The values in Fig. 3 are of course directly proportional to the percentage of $\mathrm{Pu}^{24 \mathrm{l}}$ present. If the power change due to $\mathrm{Am}^{24 \mathrm{l}}$ growth were to be limited to $0.1 \%$, the $\mathrm{Pu}^{241}$ content would have to be less than $0.002 \%$. 


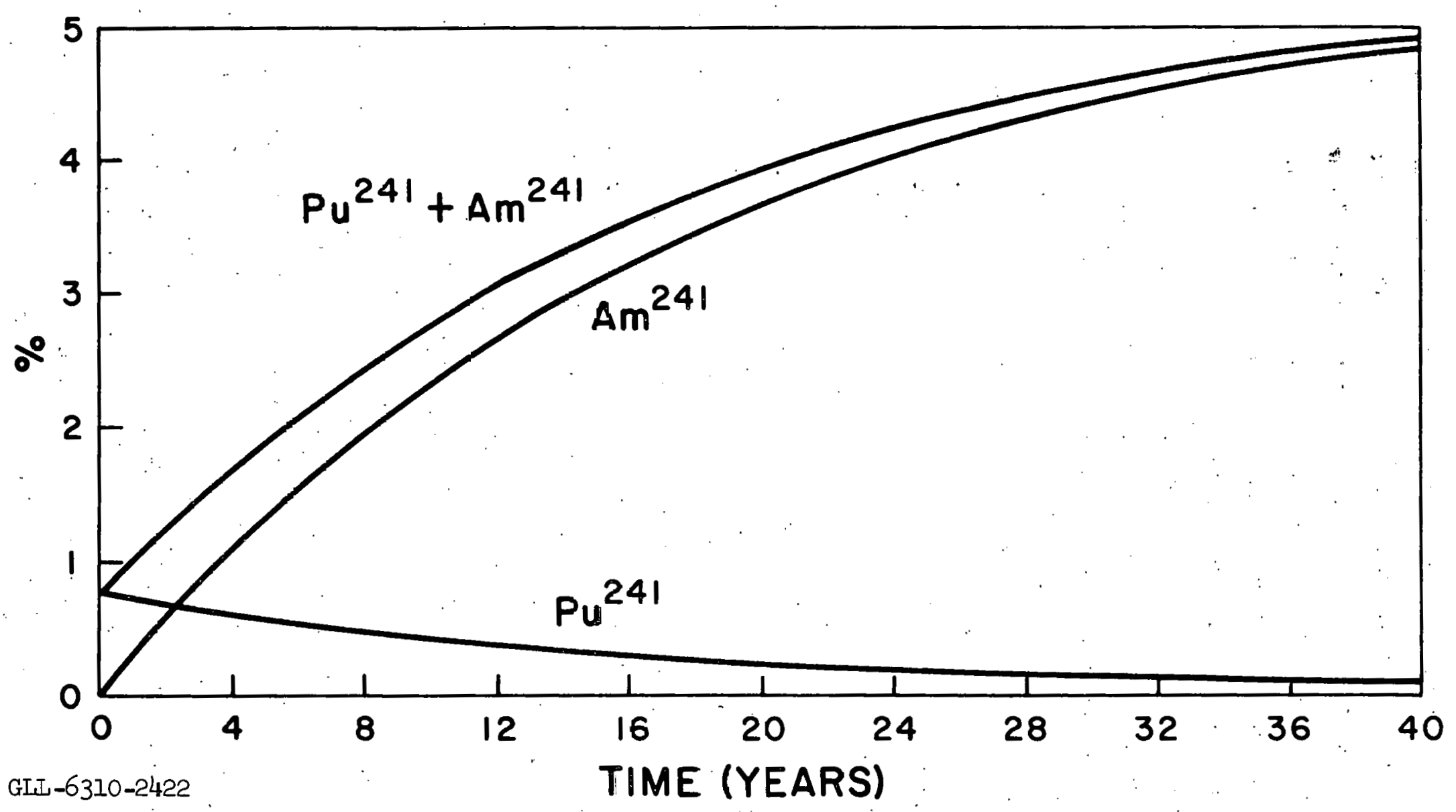

Fig. 3. Power due to $\mathrm{Pu}^{241}$ and $\mathrm{Am}^{24 \mathrm{I}}$ in plutonium. 


\section{REFERENCES}

l's. R. Gunn, UCR L-4547 (1955).

${ }^{2}$ S. R. Gunn, UCRL-5375 (1958).

${ }^{3}$ S. R. Gunn, UCRL-7490 (1963).

${ }^{4}$ S. R. Gunn, in preparation. 
This report was prepared as an account of Government sponsored work. Neither the United States, nor the Commission, nor any person acting on behalf of the Commission:

A. Makes any warranty or representation, expressed or implied, with respect to the accuracy, completeness, or usefulness of the information contained in this report, or that the use of any information, apparatus, method, or process disclosed in this report may not infringe privately owned rights; or

B. Assumes any liabilities with respect to the use of, or for damages resulting from the use of any information, apparatus, method, or process disclosed in this report.

As used in the above, "person acting on behalf of the Commission" includes any employee or contractor of the Commission, or employee of such contractor, to the extent that such employee or contractor of the Commission, or employee of such contractor prepares, disseminates, or provides access to, any information pursuant to his employment or contract with the Commission, or his employment with such contractor. 